\section{Phlebology in art}

Paolo Zamboni

Department of Cardiology, University of Ferrara; Director of the School of Specialization in Vascular Surgery and Emilia Romagna; HUB Center for Venous and Lymphatic Diseases, University Hospital of Ferrara, Italy

\section{Phlebology in art}

The post-thrombotic syndrome (PTS) is a disabling disease, which often leads to chronic venous leg ulceration. It can be treated and/or prevented after deep vein thrombosis (DVT) by the use of elastic stockings, because surgery is a highly selected option. Symptoms and complications of PTS appear several years after DVT. While varicose veins and ulcerations were extensively described in antique art and literature, the first medical case truly compatible with a PTS story was depicted in the manuscript of Guillaume de SaintPathus, in the Middle Age. ${ }^{1}$

The manuscript, entitled La vie et les miracles de Saint Louis, tells us that in 1271 Raoul, a 20-year-old Norman shoemaker, suffered from a monolateral acute oedema of the right calf. Some days later, the swelling extended up to the thigh (Figure 1A). He went to a doctor for consultation. In 1271, Raoul's phlebologist was Henri de
Perche. This confirms us that French physicians were the actual founders of phlebology. Henri suggested him to lie supine, and then wait and see. What happened a few months later, with big surprise of Raoul and his relatives, was that the swelling disappeared (Figure 1B). For a few years the leg remained healthy, but then it suddenly worsened again and developed an ulceration in the medial surface of the right ankle (Figure 1C).

At that time, the shrine of Saint-Eloi was the main center for venous leg ulceration. Raoul underwent to additional unspecified treatment attempts, but everything was unsuccessful. The last hope was to visit the tomb of King Saint Louis, where Raoul spent a few days praying the saint. Finally, he picked up some dust from below the tombstone and applied it directly onto the ulcer. This was not the first description of an advanced dressing for venous leg ulcers: in the Bassi library, Glauco Bassi's typewritten notes report other previous descriptions, starting from the Bible. ${ }^{2}$ However, the manuscript reports that the wound miraculously healed. We do not know if Raoul had recurrences later in life, as it happens in modern PTS. However, Raoul was reported to have been still alive 11 years after the Saint Louis miracle.

I wanted to study Raoul's case after reading a monograph on the history of DVT. According to Galanaud et al., ${ }^{3}$ Raoul's story was the first medical report of DVT. In ancient Greece, neither Hippocrates nor Oribasius had reported clinical cases resembling DVT, which also
Correspondence: Paolo Zamboni, Vascular Diseases Center, University of Ferrara, via Aldo Moro 8, 44124 Cona (FE), Italy.

E-mail: zambo@unife.it

Key words: Italian Phlebolymphology; history; Masters of the past; phlebology; lymphology.

Conflict of interests: the author declares no potential conflict of interests.

This paper is part of the monographic issue: 'Did the Masters of the past know the future? History and update of Italian Phlebolymphology' - Guest editor: Alberto Macciò (Phlebology - Part I edited by G. Agus; Phlebology - Part II edited by P. Bonadeo; Lymphology edited by F. Boccardo).

Received for publication: 30 June 2020.

Revision received: 10 July 2020.

Accepted for publication: 15 July 2020.

This work is licensed under a Creative Commons Attribution 4.0 License (by-nc 4.0).

( Copyright: the Author(s), 2020

Licensee PAGEPress, Italy

Veins and Lymphatics 2020; 9:9254

doi:10.4081/vl.2020.9254

applies to the art of ancient Egypt, Persia, and South America. Even Roman physicians such as Galen or Caelius reported nothing suggesting a diagnosis of DVT. We can conclude that, to the best of our knowledge, Raoul's story is the first medical report on both DVT and PTS.

\section{References}

1. De Saint Pathus G. La vie et les Miracles de Saint Louis. Paris: Bibliothèque National de France; 1330-1340.

2. Bresadola M. The Bassi Historical International Library of Phlebology at the Ferrara University Hospital. Veins and Lymphatics 2014;3:4150.

3. Galanaud JP, Laroche JP, Righini M. The history and historical treatments of deep vein thrombosis. Thromb Haemost 2013;11:402-11. 